Portland State University

PDXScholar

$5-27-2008$

\title{
"Sustainable Development": Critical Concepts in Geography
}

Tyler Vick

Portland State University

Follow this and additional works at: https://pdxscholar.library.pdx.edu/geog_masterpapers

Part of the Geographic Information Sciences Commons, Nature and Society Relations Commons, and the Remote Sensing Commons

Let us know how access to this document benefits you.

\section{Recommended Citation}

Vick, Tyler, "'Sustainable Development": Critical Concepts in Geography" (2008). Geography Masters Research Papers. 23.

https://pdxscholar.library.pdx.edu/geog_masterpapers/23

10.15760/geogmaster.23

This Paper is brought to you for free and open access. It has been accepted for inclusion in Geography Masters Research Papers by an authorized administrator of PDXScholar. Please contact us if we can make this document more accessible: pdxscholar@pdx.edu. 


\title{
"Sustainable Development": Critical \\ Concepts in Geography
}

\author{
Tyler Vick
}

Submitted for partial fulfillment of Master of Science degree in Geography Portland State University

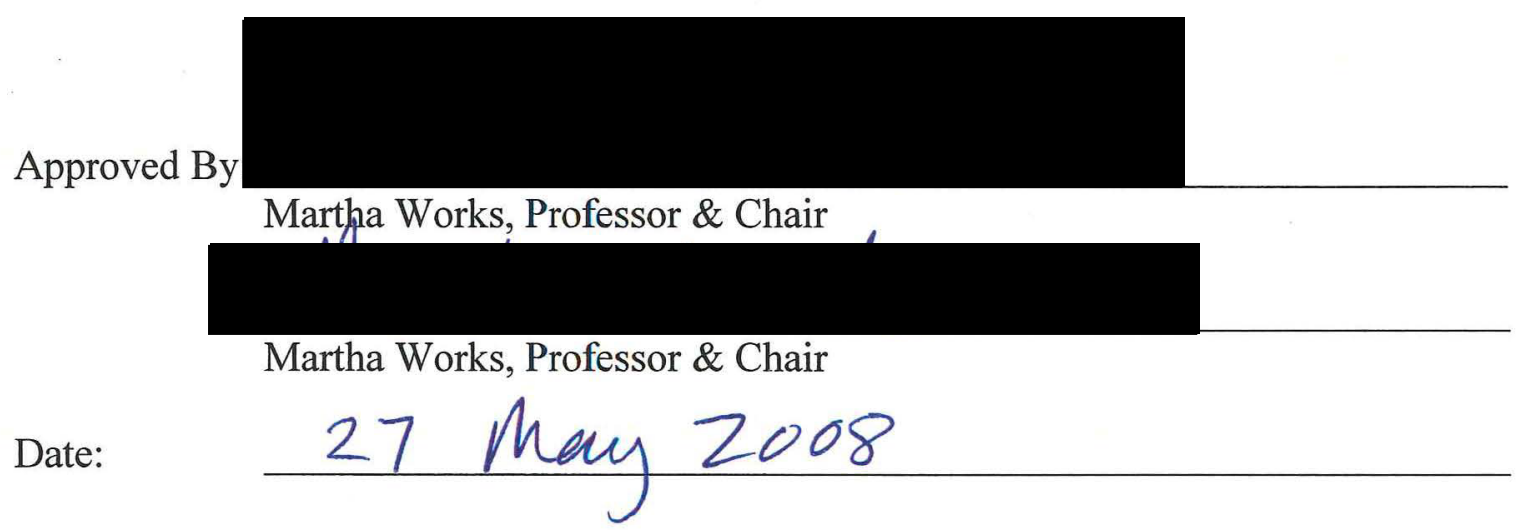




\section{Abstract}

This paper reviews significant geographic contributions to academic literature in the arenas of conservation, environmental thought, and "sustainable development", in order to understand why geographers have not been more central contributors to the sustainable development movement. A review of geographic literature reveals no lack of understanding on the "sustainable development" concept. However, the disciplines' contributions are lacking in numbers relative to published articles and in developing research and practical methods for directly benefiting the "sustainable development" movement. In fact, only a handful of geographers have made multiple literary contributions on the topic of "sustainable development."

The discipline of geography is well positioned to make positive contributions towards the "sustainable development" movement. Geographers possess strong roots in human-environment studies, the physical sciences, cross-disciplinary studies, and in geographic information systems (GIS) and remote sensing technologies. Geographers also contribute to scholarship concerning conservation, resource management, and environmental thought. Current literature is reflective of geographers understanding of the "sustainable development" concept as it relates to politics, economics, technology, and within the context of boundaries and scale.

This paper begins with a discussion on the definition of the "sustainable development" and its oxymoronic nature. Articles written prior to the 1960s provide a historical perspective on environmental thought and conservation prior to the quantitative 
and environmental revolutions of the 1960 s and 70 s, respectively. Reviews of the current geographic perspective on culture, boundaries, and scale within the framework of "sustainable development" provide geography's potential for insight concerning the many challenges facing the discipline and society in understanding and achieving sustainability. 


\section{Table of Contents}

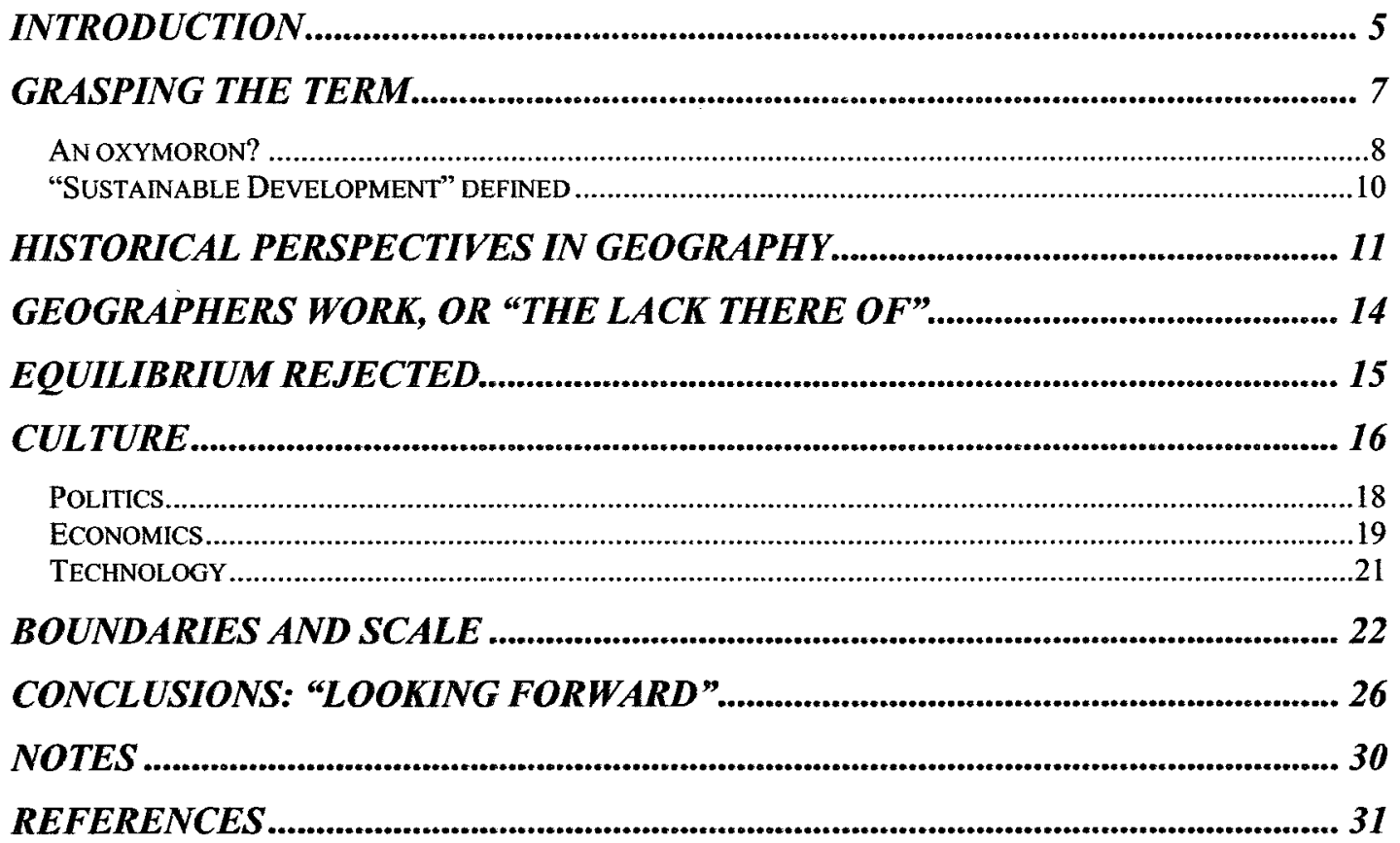




\section{Introduction}

In the field of geography, the three terms "conservation", "sustainable development", and "resource management" are fundamentally interchangeable. Regardless of how geographers might approach one of these terms, they quickly find themselves discussing all three as interrelated concepts. For this reason I've found it most practical to follow the masses in geographic literature (Adams 2002; Cavallaro 1998; Demeritt 1994; Gilbert 1993; Johnston 1993; Kates 1987; Liverman 1999; Simpson 1996; Turner 1997; Wilbanks 1994; Zimmerer 1994; Zimmerman 2001) and to lump the broad topics of conservation, resource management, energy use and population studies into and under the broad and overarching theme of "sustainable development." The goal of this paper is to present, and critique where necessary, the most common and reoccurring themes in geographic literature pertaining to the broad and cross-disciplinary topic of "sustainable development" and environmental thought in the field of geography.

This paper is divided into a series of sections and subsections for the purpose of organization and to methodically discuss the complex and reoccurring geographic themes related to sustainable development. The chronology of this paper helps simplify the subject matter in an attempt to tell the 'geographic story' and to help facilitate both readability and understanding of this complex topic. The paper first discusses the general concept of the term sustainable development, its meaning, and the oxymoronic nature of

the term. It then considers geography's historical contributions on environmental degradation, conservation and economic development beginning in 1864. These historical perspectives are then followed by a discussion of geography's most current contributions to sustainable development, or the "lack thereof." These discussions are 
followed by a review of the current mainstream geographic rejection of equilibrium, which offers insight to why environmental thought in geography has historically developed and changed over time. A section on culture and its critical components including politics, economics and technology emphasizes how each is currently playing a role, or perhaps more importantly, should be playing a role in achieving sustainable development. A review of geographic perspectives on scale and boundaries addresses how they both relate to the discussion on sustainable development. The paper ends with a review of the critical themes in realizing sustainable development, as well as suggesting how and why geography is well positioned to contribute to the subject.

In addition to the general outline of this paper, the work of two geographers who have contributed significantly to the discipline's discussion on sustainable development will be emphasized: Thomas Wilbanks and Karl Zimmerer. Wilbanks has contributed significantly to discussions on energy technology, its efficiency and on its development and use, will be relied upon. He offers insight into the intellectual value and practical utility of several of geography's distinctive concepts, including general discussions on the meaning and power of the concept, current geographic perspectives on sustainable development, and common challenges in realizing sustainability.

Second, the works of Karl Zimmerer are referenced throughout this paper. Zimmerer's has contributed significantly to discussions on biodiversity, conservation, ecology and agriculture in Latin and South America, as well as having helped advance the disciplines push toward a "new ecology". With respect to sustainable development, Zimmerer's contributions are incorporated through his insights on the "new ecology," through his discussions on the framework of 'political ecology', and in his discussions of 
ecological scales and boundaries to sustainable development.

\section{Grasping the term}

"Sustainable development" is not a singular concept or a coherent and unified movement or approach (Zimmerman 2001). Indeed, the scholarly and popular literatures are rife with competing and often contradicting notions of what exactly constitutes sustainable development. As Dowie (1995) explains, grassroots environmentalists offer one definition, while large corporations offer another, and one person's sustainability is another's exploitation. In this process, both radical environmentalists and conventional development-policy pragmatists have seized the phrase and used it to express and explain their ideas about development and environment. As a result, they have created a theoretical maze of great complexity (Adams 2002). These multiple perspectives on what constitutes sustainable development differ primarily in terms of how authors define what requires sustaining - anything from ecosystems to profitability, or from cultural lifestyles to levels of material consumption (NSF 2000). Zimmerman (2001) suggests that since there is a wide-ranging struggle to determine how sustainable development will and should be defined and used in environmental and developmental discourse, questions about what constitutes "sustainability" are first and foremost ideological, rather than ecological. In any case, geographic literature points to sustainable development becoming a catchphrase for discussion and action because it seems to capture a widespread feeling that the state of the earth is somewhat precarious.

On the one hand, we see around us evidence of progressive deforestation, a loss of biological diversity, carbon emissions beginning to drastically change our atmosphere, and growing volumes of wastes that we are unprepared to handle. Many of our fellow 
citizens have a deep sense that somehow we may have let the relationship between society and nature in this world get out of balance, that we may be creating a threat to our very survival (Wilbanks, 1994). On the other hand, not in opposition but in parallel, we see around us evidence that our economic and social systems are not delivering sustained progress toward a better life for most of the world's population (Wilbanks, 1994).

Together, these perceptions create a nagging unease that comfortable, secure human life cannot be sustained indefinitely unless we rethink the ways we live with each other and with our earth (Kaplan, 1994). This intuitive sense of a threat to human survival lies behind the power of the term "sustainable development".

One of the troublesome elements associated with "sustainable development" is the time frame in which sustainable development is defined. Simpson (1996) notes that in discussions of sustainability, the period over which it will be effective is often left unspecified, leaving the impression that development proposals of any significant scale will involve the use of some resources which are, on anything less than a geological time scale, nonrenewable. In my review of geographic literature, Simpson was the only one to question the time frame for sustainability. Does sustainable development suggest that we sustain something for the next ten years, the next century, or for eternity? For development to be considered sustainable, different types of development must be considered depending upon its sustaining time frame.

\section{An oxymoron?}

Within geography, some feel the term "sustainable geography" can be challenged on many grounds as being an oxymoron (Turner 1997; Wilbanks 1994). Wilbanks (1994) states that the majority view maintains that the developmental part of the sustainable 
development equation will call for a great deal of economic growth in order to spread benefits to a much larger proportion of the world's growing population, while the minority view holds that it's impossible to have both development and sustainability, and that no paths enable both. In this view, cultural changes are the key to sustainable development. Both developed and developing countries must learn to be content with less development. In addition, industrialized nations would have to lower their standards of living in order to balance global inequalities. Wilbanks (1994) casts doubt on the notion of trying to imagine a process of democratic decision-making at local, national, and international scales that would lead to a smooth transition into less development, and lowered standards of living.

"Sustainable development" as it relates to the historical aspect of human-environment relationships is also challenged by Turner (1997). The defining character of that history is 'development' as increasing consumption, through escalating production, and achieved by the advancing technological control of nature (Grubler 1994: 287-328). 'Sustainable' in contrast, implies that the use of nature is in some sort of long-term balance with natural biogeochemical processes, including their flux (Turner 1997). A nature so transformed that a technological substitute can match or surpass nature's biogeochemistry is, by most definitions, unsustainable. A look at this historical comparison clearly illustrates that development and sustainable constitute a paradox.

Wilbanks (1994) takes the difficulty of grasping the term a step further by implying ambiguity with the term sustainable development. Neither "sustainable" nor "development" is easy to define as either an independent or a dependent variable. But to Wilbanks, ambiguity in this case is the virtue of versatility, in that it allows and fosters a 
broad consensus about the need for global action, because different people can accept it sincerely while they mean somewhat different things by it. Turner (1997) supports this notion, describing the elusiveness and elastic qualities of sustainable development as being precisely what resonates with a postmodern, global community. Thus, in the views of both Wilbanks and Turner, the elusiveness and ambiguity of sustainable development becomes an ideal political formulation, for it provides the global community with the illusion of a broad, coherent consensus, within which an almost endless array of objectives may be pursued.

Although sustainable development is undoubtedly a 'fuzzy concept' in many respects, the concept of sustainability must be defined within global compatibilities and in relation to a given environment (Cavallaro et al. 1998) and within a local context. Wilbanks (1994) supports the notion of defining the term within a context: "Sustainable development does not mean a single answer for each place; it is strongly conditioned by social context and values and by external relationships; it is strongly path dependent; and it exhibits considerable geographic differentiation."

\section{"Sustainable Development" defined}

First outlined in the 1987 Brundtland Commission Report, Our Common Future, "sustainable development" has emerged as one of the most hotly debated and central concepts within the modern environmental thought (Dowie 1995). Sustainable development is broadly defined as "development that meets the needs of the present without compromising the ability of future generations to meet their own need" (WCED 1987). This definition has become the most familiar concept and objective to base upon the sustainability principle, and subsequently, the most widely recognized by the 
geographic community (Adams 2002; Cavallaro et al. 1998; Dowie 1995; Liverman 1999; Simpson 1996; Turner 1997; and Wilbanks 1994).

In light of the fact that geographic literature is abundant with contradicting notions as to what exactly sustainable development is, and considering Turner (1997) and Wilbanks (1994) offer a recognizable argument into the oxymoronic and ambiguous nature of the term, perhaps a different catchphrase altogether should be employed. Furthermore, the notion that sustainable development can occur without conservation or that sustainable development and conservation are two separate terms altogether is erroneous. Zimmerer (2000) suggests that instead of using the term sustainable development to try and employ the ideas of conservation and sound development, perhaps the study of environmental conservation and economic development might better be referred to as conservation-withdevelopment (Adams 1990; Bryant 1992; Conway and Barbier 1990; Emel and Peet 1989; Friedmann 1992:119-124; Redclift 1987; Schmink and Wood 1987; Sheridan 1988; Stocking and Perkin 1992). This definition is intricately linked to the multi-faceted idea of the "new ecology ${ }^{1}$."

\section{Historical Perspectives in Geography}

Geographers have for some time now been intrigued by the human-environment relationship as it relates to sustainable development. Prior to development of the term, geographers frequently described the topic through related areas such as resource management, resource destruction, conservation, and the disruption of nature's balance. Perhaps the earliest geographer to intimately discuss and provide analysis on the topic of resource management and environmental degradation was George Perkins Marsh, who in 
1864 wrote Man and Nature. George Perkins Marsh, as I see it, provided one of the first geographic perspectives and modern discussions about society's ecological problems.

David Lowenthal described Man and Nature as "the most important and original American geographical work of the nineteenth century" because of the revolution it brought about in understanding the ways that people transformed their surrounding (Lowenthal 1958: 246).

In 1933, the British geographer Hugh Rover Mill summed up the situation as follows:

"If the influence of the land on the life of Man has been reduced in the last hundred years from a tyranny to a doubtful hint, the reaction of Man on the economy of the world has grown from a jest to a serious menace. The disturbance of the balancing harmony of plant and animal distribution and the exhaustion of mineral deposits has no precedent in the life of species other than Homo sapiens, and unless he vindicates his name by bringing reason to the rescue of his future, there is no doubt that Nature will ultimately take the matter in hand and restore equilibrium in her own drastic and remorseless way."

As early as 1938, Carl Sauer produced two perceptive statements on the detrimental effects of human agency on earth. He wrote about the economic plunder of natural resources that came about with the diffusion of new and technological superior societies (Sauer 1938), and he identified the central role of destructive exploitation in the growth of "wealth" of the modern world that was accepted commonly as a normal process, excused and even approved of as a "stage" of economic "development" (Williams 1994). According to Sauer, the concerns over the geographical and environmental implications of the industrial revolution, the expansion of colonization, the toll of raw materials funneled through world commerce into consumer goods, and what was happening to the individual, the non-conformist group, have not been addressed by historical geographers but by economically or politically minded geographers conscious of the importance of an historical perspective (Sauer 1938; Williams 1994). 
In 1941, Whitaker wrote "Sequence and Equilibrium in destruction and conservation of natural resources". In this article, he suggested that types of equilibrium (i.e. levels at which resource depletion and renewal are in balance) can be recognized. He believed that before man comes into an area most if not all resources are in a state of equilibrium, and that man is continually upsetting the balance of nature (Whitaker 1941). Whitaker claimed he could recognize situations where the balance of nature or equilibrium was stable, unstable, or neutral.

In 1955, Edward Price embraced the concept of culture and conservation and its undeniable relationship with future generations in his paper "Values and Concepts in Conservation." The underlying arguments by Price (1955) were based on questions involving the conservation of natural resources hinging upon the concepts and values of the future.

Well into the 1960's the Human-Environment tradition flourished, but what geographers did not do or could not do, was to collectively provide the disciplinary leadership for the environmental revolution (Kates 1987). The 1960s brought about the quantitative revolution, which was disciplinary (Burton 1963); while the environmental revolution was social (Kates 1987). No discipline was better situated for the environmental revolution than geographers to provide intellectual and scientific leadership. Kates maintains that the natural science for the environmental revolution should have been the science of the human environment. Unfortunately, it did not happen that way.

The early 1970s were a critical period in the development of environmental research and policy. Growing concern about environmental degradation and pollution catalyzed 
the public protest and political response now commonly termed "the environmental movement" (Liverman 1999). By 1980, a new set of environmental concerns were emerging onto the international agenda, including ozone depletion, climate change, and biodiversity loss. These issues became defined as "global" environmental changes and were widely publicized by scientists, environmental groups, and some national governments. By the end of the 1990s, geographers were becoming closely identified with the interdisciplinary field of the "human dimensions of global environmental change," mainly through the study of the social causes of land-use change and through critical perspectives on international environmental policy (Liverman 1999).

\section{Geographers Work, or "The Lack There Of"}

While it is obvious that geographers possess the traditionally strong humanenvironment, holistic, and cross-disciplinary skills to contribute significantly to the study of "sustainable development", many geographers criticize the lack of work by geographers in the environmental, conservation, and sustainable development movements. As pointed out by Liverman (1999), geographers played a relatively minor role in the Stockholm conference and subsequent environmental policy formation, and wrote few of the popular environmental texts of the 1970s, the decade immediately following the environmental revolution.

Demeritt (1994) criticism stems from geographer's tendency to produce socially thin environmental impact statements without enough of the caring and reflexive moral engagement that must be made with the world in this era of global change. According to Demeritt (1994), we need a more fully critical effort that both diagnoses the deeper social 
and economic causes of present environmental problems and points the way forward to some preferable future that we might make for ourselves. In marked contrast to their colleagues interested in less developed countries, geographers writing about North American have not been up to this critical task (Demeritt 1994).

Gilbert (1993) expresses his sadness in today's professional geographers and their lack of widespread interest among the profession in addressing these key environmental issues. According to Gilbert (1993), many geographers appear to be looking inward at their discipline rather than asking its relevance to over-arching concerns of their nations and of world society.

\section{Equilibrium Rejected}

One the biggest changes in the field of geography, as well in other academia, is the fundamental rejection of the historical assumption in the balance of nature. The idea that the environment is always in a state of harmonious equilibrium before the intervention of man has been fundamentally rejected by geographers and began to noticeably show up in literature beginning in the late 1980s and continuing through the present (Cavallaro et al. 1998; Demeritt 1994; Kates 1987; Wilbanks 1980; Zimmerer 1994; Zimmerer 2000). From a historical perspective, it's important to point out that this outdated idea of stable, holistic ecosystems was used by many environmental historians and Green critics to measure and assail the environmental damage wrought by society (Demeritt 1994).

Zimmerer (2000) not only describes the once-abiding belief in a balance of nature as now deeply questioned and, but in many quarters, it's now rejected outright. Instead, a large number of cornerstone ecological processes are described as nonequilibrium dynamics and long-term shifts, and historical conditionalities such as path dependencies 
and trajectories ${ }^{2}$ (Zimmerer 2000). Accordingly, the current understanding of ecological landscapes is claimed to be a "new ecology" or, at the least, an ecological "paradigm shift" (Botkin 1990; Wu and Loucks 1995; Zimmerer and Young 1998). The "new ecology" accents disequilibria, instability, and even chaotic fluctuations in biophysical environments, both "natural" and human-impacted (Vale 1982; Zimmerer 1994). According to Zimmerer (1994), this emphasis on the volatility of environmental change tests the conventional ecological wisdom that depicts nature as tending toward stability or near-constant balance. Instead, the "new ecology" proclaims opposition to the idea of persistent stability in environmental systems. In any event, the dangers of the legitimation of environmental damage wrought by humans will have less to do with the ideas of the "new ecology" and more to do with their manipulation in planning and policy-making processes (Zimmerer 1994).

\section{Culture}

The fundamental ideology of culture is critical in understanding sustainable development. Culture not only shapes how people identify and evaluate elements of their environment, and influences their behavior and subjective experiences, culture provides the social infrastructure and institution that determine how resources are used and managed. Despite claims to objectivity and scientific rigor, cultural imperatives apply equally to the way western resource managers' deal with environmental issues (Jay and Morad 2002). Jay and Morad (2002) argue that although cultures do develop, any changes that happen are predicated on slow-evolving beliefs, assumption and practices, whereas, environmental institutions and behaviors that incorporate long-term patterns of settlement and land us are much more likely to succeed than those built on short-term 
agendas.

During the 1992 International Geographical Congress, former U.S. Senator Gaylord Nelson argued that the key to unlocking real sustainability is a much stronger and more widely-shared environmental ethic (Nelson 1992) - to which we might add a stronger social ethic as well. Wilbanks (1994) suggests that it's very possible that sustainable development will require an ethical revolution to go along with the other revolutions of our time: globalization, scarcity, information, and democratization. If this is true, then geography's challenge becomes much more than our traditional roles as scholars and practitioners to our roles as teachers (in the fullest sense) and as citizens who advocate the principles of economic fairness and nature society balance (Wilbanks 1994). For example, future research might address subtle connections between equity and self interest (Wilbanks 1991), which might include evaluating solid empirical relationships in cultural ecology and political economy, and between doing good and doing well (Wilbanks 1994). I would argue that a suggested ethical revolution might first benefit through understanding the relationship between culture and sustainable developments defining premise; protecting the interests of future generations.

I'm intrigued by Price's 1955 article, perhaps more than any other geographic literature work on the subject, because for me, he gets to the bottom of the cultural and ideological shortcomings associated with implementing sustainable development. Price (1955) argues that culture and conservation have an undeniable relationship with the future. Price states that,

"the distant future may be non-existent to primitive man, whose thought begins with the tangible and finds trouble enough in what can be seen, but not understood....even his past enjoys an existence that the future cannot. Since it is likely that the human will inhabit 
the earth in the future, what is our relation to them?"

Few people today accept the idea of leaving great blocks of our resources untouched. Not only do the uncertainties of the future allow us to use more resources now, but Price (1955) argues that western society in general believes that we should make a reasonable effort to keep stock resources from becoming unavailable in the future, but not at the expense of depriving large numbers of people of their use.

\section{Politics}

Wilbanks (1994) stresses that sustainable development is a concept that is fundamentally political. Its realization lies in answers to such questions as who is in control, who sets agendas, who allocates resources and who mediates disputes. In practice, development planning usually takes place within political jurisdictions, not within natural boundaries (Adams 2002). Human-made boundaries rarely fit the spatial patterns of natural systems, and more often than not, ecosystems straddle political boundaries.

Johnston (1993) argues that although people may decide in some situations, either individually or collectively, to reduce pressures on the environment, such altruism is rare and usually only on a very small scale. In reality, there is only one such institution - the state, hence the need for the state to regulate what individuals (including firms) do to the environment. Johnston (1993) suggests that if we are to accept the argument that environmental problems cannot be confined within the territory of individual countries then logically we need an international state to regulate environmental use globally. However, presently there is no international body which can produce and enforce such regulation. 
Zimmerer (2000) suggests that considerations for conservation policy and politics are provided in the framework of 'political ecology'. In general, the perspective of political ecology belongs to the part of geography described as nature-society, cultural ecology, human environment, or people-environment. Works in this general area share a concern for the combination of environmental analysis of biogeophysical conditions with a stress on broadly social factors (including political, economic, and cultural practices) as the major causes of human-induced environmental change (Grossman 1998; Turner 1997; Zimmerer 1996b). This view seeks to contribute both to sound environmental management (including nature conservation) and to the empowerment of disadvantaged social groups. Many abuses that have stemmed from conservation polices are rooted in the belief, held by policymakers, politicians, scientists, and administrators, of a balance of equilibrium-tending stability in nature (Zimmerer 2000).

\section{Economics}

Sustainability in general, is often thought to be at odds with economic development. Generally, a blanket application of sustainable development is likely to run into public, commercial and political opposition. Simpson (1996) suggests that when there is significant conflict between economic and environmental objectives, the application of principles of sustainability is much more likely to be acceptable if there is quantitative information on what environmental damage is likely to occur. What is perceived as 'economic damage' is not likely to be acceptable without firm evidence that there is no alternative, if environmental damage is to be avoided (Simpson 1996).

A further distinction which must be made involves the differing perceptions of economic development and sustainability in industrialized nations vs. developing nations. 
People in industrialized countries tend to focus on environmental management with as little negative impact on economic development as possible (Wilbanks 1994). Whereas, people in developing countries, tend to focus on economic development with as little negative impact on the environment as possible (Wilbanks 1994). The general themes of environment and development are shared, but the objective functions are different. As a result, sustainable economic progress that reduces the gap between the wealthy and the poor of the world will mean ever-heavier demands on a physical environment that is already seriously under stress (Wilbanks 1994).

In any case, I would agree with Wilbanks (1994) in believing that at some point, and perhaps very soon in some areas, persistent exploitation of the physical surroundings will exact a growing economic and social price in diminishing resources and/or increasing pollution. Eventually, that environmental price will rise to the point where economic progress is unsustainable. This thought, better known as "carrying capacity", is central to the discussion of sustainable development. This concept is defined as the maximum population size that can be regularly sustained by an environment. Zimmerer (1994) more precisely defines carrying capacity as a given biophysical environment that exists in equilibrium with a certain population of organisms. However, how can the carrying capacity of a given population within an environment be determined if the general concept of equilibrium has already been fundamentally rejected by Geographers?

Instead, empirical evidence demonstrates a remarkable lack of temporal homogeneity in biophysical environments owing to the prevalence of unpredictable ecological disturbances such as drought (Zimmerer 1994). The assumption of the spatial homogeneity of environments, that is, environmental differences are either insignificant 
or regular in their occurrence is also fundamentally rejected. In addition, spatial homogeneity and temporal homogeneity have become related by assuming regularity in temporal variation, resulting in the inference of spatial evenness (Zimmerer 1994). These assumptions have in turn been embedded in calculations of carrying capacity (Bernard 1985; Campbell 1986). As a result, the assumption of a "continuing steady-state basis" embedded in the definition of carry capacity (Whitaker 1975) is simply unwarranted. Calculating carrying capacity, therefore, might instead be better approached through the concept employed in the "new ecology" (Botkin 1990; Wu and Loucks 1995; Zimmerer 1994; Zimmerer and Young 1998). On the outset, we must recognize the important roles of temporal disturbance and spatial variation in environments.

In fact, behind the perceived crisis of human ecology and social economy lies a third perceived crisis of demography - human population increase - which adds to the sense of urgency about the other two (Wilbanks 1994). Wilbanks (1994) argues that this notion of linking long-term equitable economic progress with a balanced relationship with our physical environment is what, in the end, makes the notion of sustainable development distinctive ${ }^{3}$.

\section{Technology}

The debate over whether technology will substitute and/or prevent environmental degradation in the future is an ongoing debate. Even in 1955, Price suggested that society would be hopeful that technology will so broaden our resource base that we will not have to worry about depletion of our present resources. At best, the rational claim that environmental problems are solvable by technical means is questionable (Jay and Morad 2002; Price 1955; Wilbanks 1994). A best guess is that our innovativeness may 
buy time to put off making the hard decisions without sacrificing economic opportunity and environmental quality in the present (Wilbanks 1994). The problem of course, is that the longer we wait, the more compounded the difficult decisions become.

One interesting technological tool that may help to communicate the idea of sustainable development is the power of visualization in this age of an information revolution ${ }^{4}$. No other form of communication is as powerful among such a wide variety of audiences, including scholars who are trying to associate creative thinking with empirical observations (Wilbanks 1994). Wilbanks (1994) describes that the creation and diffusion of visual images is displacing the printed word as a triggering mechanism for issue identification, constituency building, and agenda-setting. And visual images, including computer mapping and aerial photography, are increasingly used to identify threats to sustainability and to examine alternative paths (Wilbanks 1994). According to Wilbanks (1994), it may not be coincidental that the growing concern about global environmental sustainability coincides with humanity's exposure to images of the earth from space. As a result, there is increasing promise for geographic information systems (GIS) and remote sensing to be part of the field's contribution to the art and science of sustainable development.

\section{Boundaries and Scale}

The question of scale has historically and fundamentally been integrated into the field of geography. Hence the geographical scale for applying sustainable principles has been a primary concern to geographers. Resource sustainability is usually thought of as global, although national boundaries and ownership distort the picture (Simpson 1996). What is sustainable and controllable locally may be neither sustainable nor controllable 
globally. This becomes even more difficult considering we can all recognize that the Earth's environment and the global economy comprise a single large interactive system. We can subdivide the global system into various subcomponents for the purpose of research, but we are well aware that the parts are all inter-connected, and that what occurs in one sub-system in one place can well have an impact on another sub-system somewhere else (Johnston 1993).

In most cases the concept of sustainability is applied on the global scale. The familiar concepts, such as "globalization", "global warming", and "human dimensions on global change", describe how the message launched by the debate on sustainable development, together with the one on suitability, has been that on the global scale. However, as Cavallaro (1998) points out, it can't be ignored that sustainable development has to start from a series of local actions. Environmental problems must force a rethinking of the relations between the economy and environment on the local scale, where they originate (Cavallaro 1998).

Wilbanks (1994) argues that environmental and economic systems that need to be sustained may be more viable - or only viable - at a certain geographic scale, and that scale may differ from the scale that is most appropriate for human self-determination. In order to understand global change we must understand how actions and processes operating at one scale, say global, relate to actions and processes at another, say regional or local (Wilbanks 1994). From one direction, it is easy to see how local conditions may be affected by global economic and environmental processes, but it is hard to see how global processes may be affected by local actions (Wilbanks 1994). However, from the other direction, it is clear that global processes are in fact the result of a myriad of local 
decisions. It is also clear that many of the complex relationships among environment, economy, and society at the global scale can only begin to be unraveled by careful locality-specific research (Wilbanks 1994). This is doubly true if localities are going to be given a chance to determine their own paths, since we do not yet have a sound understanding of how processes at different scales interact with one another (Meyer et al. 1992; Harvey 1989; Soja 1989).

Zimmerer (2000) defines scale in relation to today's conservation boom more precisely. In particular, scaling is often described and employed as the zone or area of particular types of land or resource use. Scaling of the land-use zone is deployed as a means for limiting the sorts of resource practices that can be carried out, while, at the same time, containing those practices within geographically fixed areas (Zimmerer 2000). Zimmerer argues that this fixing of land-use zones as typically the major type of scaling within conservation territories. Typical zones include the use of "buffer zones," "cultural zones," and "transitional zones" as common containers of land use (Zimmerer 2000). According to Zimmerer, this existing concept of the spatial fixing of scaling is the source of serious flaws in today's conservation management. Social criticisms derive from the common practice of scaling the use areas so that they are static and relatively homogeneous (Vandergeest 1996; Zimmerer 1999). As a result, the scaling of zone-type units on the basis of one or a few defining land use or ecological traits is typically part of the map-based spatial management of units within conservation territories (Zimmerer 2000).

Instead, conservation zones should be approached as dynamic and inclined toward modification (Zimmerer 2000), and the concepts of ecological flux, rather than fixity, 
should be integrated into ideas of ecological scale and conservation (Allen 1998; Hobbs 1998). In any case, both nonequilibrium ecological science and the social critics of present-day conseryations suggest that the perceptions and practices of the land and resource users should be basic to conservation scaling (Zimmerer 2000).

The concept of boundaries has additionally distorted the picture of resource sustainability, which again is usually thought of on a global scale. What is sustainable and controllable locally may be neither sustainable nor controllable globally (Simpson 1996). Therefore, cross-boundary impacts, as suggested by Simpson (1996) should become commonly occurring theme locally, regionally and nationally (Simpson 1996). For example, power stations and industries may pollute air and water in neighboring authority areas downwind or downstream.

Sustainable development will also need boundary systems that correspond more or less to the scale at which it is carried out. For example, our national boundary systems in many parts of the world are both too large and too small to handle such challenges as sustainable development: too large for the mediation of complicated issues to be handled in a participative manner and too small for the necessary resources to be allocated in ways that will get the job done (Bell 1989).

Zimmerer (2000) suggests that boundary making for conservation runs the risk of simply walling-off the worsening degradation of many environments (including those of spatially distinct sacrifice areas) from the territories of today's conservation boom. These problems with conservation boundaries have been produced by the emphasized spatial unevenness of environment-development conditions. The buffer zones, cultural zones, and transition zones, which were once thought to soften and make more flexible the 
boundary of conservation areas, but instead are functioning in many cases as rigid demarcations (Zimmerer 2000). As a result, the boundaries of current conservation areas seem to cleave apart the privileged spaces of nature protection and preservation from those places of heavier human use and inhabitance (Zimmerer 2000). In many cases, this problem is associated with the ways in which some political jurisdictions are awkwardly bounded.

Zimmerer (2000) suggests that instead, a series of "multiple dynamic boundaries" should be formed through ongoing interactions between the managers of conservation territories and other institutions, social groups, and individuals. Making boundaries that are more openly negotiated, and that encompass a multiplicity of distinctions, is one promising proposal for reconsidering the geographical strategies of conservation (Morehouse 1996). However, enabling multiple boundaries of conservation that are both flexible and formed through negotiated processes is likely to require the role of responsible, cooperating state institutions (Zimmerer 2000). This sizeable challenge for conservation is redoubled by the effect of globalization processes, neoliberal policies, and the general "hollowing out" of national governments (Zimmerer 2000).

\section{Conclusions: "Looking Forward”}

Several critical concepts must be addressed in order for sustainable development to become a reality. Sustainability, even if defined in a general, global framework, must be related to specific spatial and temporal contexts, and above all must be related to the concept of local development (Cavallaro 1998). Furthermore, the study of crossboundary impacts must be integrated into development, at all geographic scales. In the long term, sustainable development is probably unrealizable in most localities until is 
also approached in most others (Wilbanks 1994). According to Wilbanks (1994), unless and until development is sustainable nearly everywhere, the global system remains a threat to local sustainability nearly everywhere because it tends to spread instability from place to place: for example, through population migration, the transport of environmental degradation, political conflict, or economic exploitation.

As many geographers have pointed out, technology may buy us time to put off the hard decisions without sacrificing economic opportunity and environmental quality in the present. Of course, the longer we wait, the more difficult the decisions become. Society runs the risk of ultimately wearing out our tendency to turn towards technology for preventive and substitution resolutions. In order to achieve sustainable development, something will have to give - and that is an excruciating prospect (Wilbanks 1994).

The notion that sustainable development may very well require an ethical revolution and a revolution in expectations to go along with the other revolutions of our time (i.e. globalization, scarcity, information, and democratization) is perhaps society's biggest challenge. Both cultural and ethical changes are needed since both ultimately influence and construct our economic and political structures. In addition, cultural values need to reevaluate our relationships with future generations and establish firm timeframes to what exactly we're trying to sustain.

The central question in sustainable development is whether, during the next century or two, or even in the next generation or two, the world can simultaneously sustain four thing: 1) economic development for all; 2) reasonable environmental stability; 3) continued population growth; and 4) decision-making without coercion (recent events suggest that coercion is not sustainable as a basic mode of mediation under conditions of 
widespread information flow) (Wilbanks 1994). In order to be able to have all four, we will have to be able to be highly innovative in improving our understanding of complex systems, their resilience, and their propensity to change; and in creating options that take the pressure off through technological and institutional change (Wilbanks 1994). If these four things cannot simultaneously be sustained, then perhaps the scale of development, the issues pertaining to technology, and most importantly, culture and its underlying ethical shortcomings need serious reevaluation.

For geographers, both the seriousness of these issues and the power of their terms are challenges that should be very welcome (Wilbanks 1994). Seldom does an academic discipline have an opportunity to draw so deeply upon its strengths to contribute so profoundly to questions of such significance to social decision-making (Wilbanks 1994). Geographers currently have at hand the empirical and theoretical tools with which to enter and lead pragmatic debates about sustainable development, and with which to explore and understand their implications (Adams 2002). Both tasks are important, for the discipline and for their potential contribution to the growing internal debate (Adams 2002). Geographer's central challenge, therefore, is to help plot the course of research and policy in which the human venture is truly harmonious with the immensely variegated and complexly interrelated and fragile biosphere of which it is a part (Gilbert 1993).

As Kates (1987) puts it, the great questions pertaining to sustainable development and of the human environment have at least three characteristics in common: they persist, they matter, and they are not uniquely geographical. Sustainable development has roots and a large following in many disciplines, but probably none is as relevant to it as 
geography (Adams 2002). Where else can the science of the environment be married with an understanding of the economic, political, and cultural change that geographers have developed (Adams 2002)? What other discipline offers insights into both environmental change and environment management, and who but geographers can cope with the diversity of environments and countries, and the sheer range of spatial scales, at which it is necessary to work to understand processes of human use of nature and the dynamics of the environment (Adams 2002)? The challenge to the discipline of Geography in the end is to decide whether we will contribute our holistic approaches, our scientific methods, our cross-disciplinary training, our emerging capabilities in the GIS and remote sensing fields, and our strong tradition of studying the human-environment relationship, in the implementation of sustainable development. Or will we continue to stand back and let other, perhaps less-qualified disciplines, take the lead? 


\section{Notes}

1. The term "new ecology" has been used since the 1980s to describe a major theoretical shift in the field of biological ecology (Colwell 1984; 1985; 1992). Whereas systems ecology regards environments at various scales or systems tending toward equilibrium and homeostasis (Laszlo 1972; Margalef 1968; E.P. Odum 1969; H. Odum 1983), the "new ecology" proclaims opposition to the idea of persistent stability in environmental processes (Zimmerer 1994). Instead, "new ecology" calls attention to the instability, disequilibrium, and chaotic fluctuations that characterize many environmental systems (Zimmerer 1994).

2. Far reaching questions about the previous assumption of a balance of nature are being advanced by several fields of the science, social sciences, and humanities. Ecological science clearly is one of the most prominent sources of this questioning, especially since the nature of "nature" is typically taken to be biotic above all else (Zimmerer 2000). A non-equilibrium perspective formulated in the fields of geomorphology and climatology, where this view holds a more pronounced long-term presence, also contributes to questioning the assumption of a balance of nature (Phillips 1995; Zimmerer and Young 1998).

3. Some prefer the term "sustainability" to "sustainable development" because it seems less oxymoronic, at least partly because it concentrates on continuity rather than change. One can argue, however, that use of the term "sustainable development" makes it more difficult to avoid the central challenge, which is to combine sustainable environmental management with sustainable human economic and social progress (Wilbanks, 1994).

4. Visualization is defined as the "use of concrete visual representations to make contexts and problems visible" in order "to engage the most powerful human information-processing abilities" (MacEachren et al. 1992:101) 


\section{References}

Adams, W. M. 1990. Green Development: Environment and Sustainability in the Third World. London: Routledge.

.2002. Sustainable Development?. In Geographies of Global Change. ed. R.J. Johnston, P.J. Taylor, and M.J. Watts, 412-426. Blackwell: Blackwell Publishers.

Allen, T.F.H. 1998. The Landscape "Level" is Dead: Persuading the Family to Take It of the Respirator. In Ecological Scale: Theory and Applications, ed. D.L. Peterson and V.T. Parker, pp. 35-44. New York: Columbia University Press.

Bell, D. 1989. American Exceptionalism Revisited: The Role of the Civil Society. The Public Interest 95: 35-58.

Bernard, F.E. 1985. Planning and Environment Risk in Kenyan Drylands. Geographical Review 75(1): 58-70.

Botkin, D.B. 1990. Discordant Harmonies: A New Ecology for the Twenty-first-Century. New York: Oxford University Press.

Brundtland, G.H. 1987. Our Common Future. Oxford: Oxford University Press for the World Commission on Environment and Development.

Burton, I. 1963. The quantitative revolution and theoretical geography. Canadian Geographer 7(4): 151-162.

Bryant, R. L. 1992. Political Ecology: An Emerging Research Agenda in Third-World Studies. Political Geography 11(1):12-36.

Campbell, D.J. 1986. The Prospect for Desertificiation in Kajaido District, Kenya. Geographical Joumal 15(1): 44-55.

Cavallaro, V. 1998. Sustainable development: global or local?. GeoJournal 45(1-2): 3340.

Colwell, R.K. 1984. What's New? Community Ecology Discovers Biology. In A New Ecology: Novel Approaches to Interactive Systems, ed. P.W. Price, C.N.

Slobodchikoff, and W.S. Gaud, pp. 387-396. New York: Wiley. . 1985. The Evolution of Ecology. American Zoologist 25: 771-777.

1992. Making Sense of Ecological Complexity: A Personal and Conceptual Retrospective. Biotropica 24(2b): 226-232. 
Conway, G. R., and Barbier, E. B. 1990. After the Green Revolution: Sustainable Agriculture and Development. London: Earthscan.

Demeritt, D. 1994. Ecology, objectivity and critique in writings on nature and human societies. Journal of Historical Geography 20(1): 22-37.

Dowie, M. 1995. Losing Ground: American Environmentalism at the Close of the Twentieth Century. Cambridge, MA: MIT Press.

Emel, J., and Peet, R. 1989. Resource Management and Natural Hazards. In New Models in Geography: The Political Economy Perspective, Vol. 1, ed. R. Peet and N. Thrift, pp. 49-76. London: Unwin Hyman.

Foster, D.R. 2000. From Bobolinks to Bears: Interjecting Geographical History into Ecological Studies, Environmental Interpretation, and Conservation Planning. Journal of Biogeography 27(1): 27-30.

2002. Insights from Historical Geography to ecology and conservation: lessons from the New England landscape. Journal of Biogeography. 29: 1265-1275.

Friedman, J. 1992. Empowerment: The Politics of Alternative Development. Oxford: Blackwell.

Gilbert, W.F. 1993. The Global Environment: What Can We Do?. GeoJournal 30(4): 367-368.

Gregory, D. 1994. Geographical Imaginations. Oxford: Basil Blackwell.

Grossman, L. 1998. The Political Ecology of Bananas. Boulder, CO: Westview Press.

Grubler, A. 1994. Technology. In Changes in land use and land cover: a global perspective. W.B. and Turner II, B.L. (eds). Cambridge: C.U.P: 287-328.

Harvey, D. 1974. Population, Resources, and the Ideology of Science. Economic Geography 50(3): 256-277. . 1989. The Growth of Postmodernity. Baltimore: Johns Hopkins University Press.

Hobbs, R.J. 1998. Managing Ecological Systems and Processes. In Ecological Scale: Theory and Applications, ed. D.L. Peterson and V.T. Parker, pp. 459-84. New York: Columbia University Press.

IUCN. 1980. The World Conservation Strategy. Geneva: International Union for Conservation of Nature and Natural Resources, United Nations Environment Program, World Wildlife Fund. 
1991. Caring for the Earth: A Strategy for Sustainable Living. Gland: International Union for Conversation of Nature and Natural Resources.

Jay, M., and Morad, M. 2002. Cultural Outlooks and the Global Quest for Sustainable Environmental Management. Geography 87(4): 331-335.

Johnston, R.J. 1993. Tackling Global Environmental Problems. Geography Review. January: 27-30.

Kaplan, R.D. 1994. The Coming Anarchy. Atlantic Monthly 373(2): 44-76.

Kates, R.W. 1987. The Human Environment: The Road Not Taken, The Road Still Beckoning. Annals of the Association of American Geographers 77(4): 525-534. . 1995. Labnotes from the Jeremiah experiment: hope for a sustainable transition. Annals of the Association of American Geographers 85(4): 623-640.

Lazlo, E. 1972. The Systems View of Nature. In The Systems View of the World, ed. E. Lazlo, pp. 19-46. New York: George Braziller.

Liverman, D.M. 1999. Geography and the Global Environment. Annals of the Association of American Geographers 89(1): 107-120.

Low, N. and Gleesan, B. 1998. Justice, Society and Nature: An Exploration of Political Ecology. London: Routledge.

Lowenthal, D. 1958. George Perkins Marsh: Versatile Vermonter. New York: Columbia University Press.

MacEachren, A.M., Butterfield, B., Campbell, J.B., DiBiase, D., and Monmonier, M. 1992. Visualization. In Geography's Inner Worlds, ed. R.F. Abler, M.G. Marcus, and J.M. Olson, pp. 99-137. New Brunswick: Rutgers University Press.

Mannion, A. M. 1991. Global Environmental Change: A Natural and Cultural Environmental History. New York: Longman.

Margalef, R. 1968. Perspectives in Ecological Theory. Chicago: University of Chicago Press.

Marsh, G.P. 1864. Man and Nature. New York: Scribner, Armstrong and Co.

Meyer, W.B., Gregory, D., Turner, B.L., and McDowell, P.F. 1992. The Local-Global Continuum. In Geography's Inner Worlds, ed. R.F. Abler, M.G. Marcus, and J.M. Olson, pp. 255-279. New Brunswick: Rutgers University Press. 
Morehouse, B.J. 1996. A Place Called the Grand Canyon: Contested Geographies. Tucson: University of Arizona Press.

Nelson, G. 1992. Presentation in Plenary Session on "The Global Environment: What Can We Do.” International Geographic Congress, Washington, D.C., August 10, 1992.

NSF (National Science Foundation Workshop on Urban Sustainability). 2000. Towards a Comprehensive Geographical Perspective on Urban Sustainability. Available http://policy.rutgers.edu/cupr.

Odum, E.P. 1969. The Strategy of Ecosystem Development. Science 164: 262-270.

Odum, H. 1983. Systems Ecology. New York: Wiley.

Phillips, J.D. 1995. Biogeomorphology and Landscape Evolution: The Problem of Scale. Geomorphology 13: 337-47.

Price, Edward T. 1955. Values and Concepts in Conservation. Annals of the Association of American Geographers. 45(1): 64-84.

Redclift, M. 1987. Sustainable Development: Exploring the Contradictions. London: Methuen.

Schmink, M., and Wood, C.H. 1987. The "Political Ecology" of Amazonia. In Lands at Risk in the Third World: Local Level Perspectives, ed. P.D. Little and M.H. Horowitz, pp. 38-57. Boulder, Colorado: Westview Press.

Sheridan, T.E. 1988. Where the Dove Calls: The Political Ecology of a Peasant Corporate Community in Northwestern Mexico. Tucson: University of Arizona Press.

Simon, J.L. 1996. The ultimate resource 2. Princeton, NJ: Princeton University Press.

Simpson, B. 1996. Sustainability and Environmental Assessment. Geography 81(3): 205216.

Soja, E.W. 1989. Postmodern Geographies: The Reassertion of Space in Critical Social Theory. London: Verso.

Stocking, M., and Perkin, S. 1992. Conservation-with-Development: An Application of the Concept in the Usambara Mountains, Tanzania. Transactions of the Institute of British Geographers 17:337-349.

Suaer, C. 1938. Theme of plant and animal destruction in economic history. Journal of Farm Economics 20: 765-775. 
Turner II, B.L. 1997. The Sustainability Principle in Global Agendas: Implications for Understanding Land-Use/Cover Change. The Geographical Journal 163(2): 133-140.

Vale, T.R. 1982. Plants and People: Vegetation Change in North America. Washington, D.C.: Association of American Geographers.

Vandergeest, P. 1996. Mapping Nature: Territorialization of Forest Rights in Thailand. Society and Natural Resources 9: 159-75.

WCED (World Commision on Environment and Development). 1987. Our Common Future. Oxford: O.U.P.

Whitaker, J.R. 1940. World View of Destruction and Conservation of Natural Resources. Annals of the Association of American Geographers. 30(3): 143-162. . 1941. Sequence and Equilibrium in Destruction and Conservation of Natural Resources. Annals of the Association of American Geographers. 31(2): 129-144.

Whittaker, R.H. 1975. Communities and Ecosystems. New York: MacMillan.

Wilbanks, T. 1980. Location and Well-Being. New York: Harper and Row. 1984. Scale and the Acceptability of Nuclear Energy. In Nuclear Power: Assessing and Managing Hazardous Technology, ed. M. Pasqueletti and D. Pijawka, pp. 9-50. Boulder: Westview.

. 1988. Impacts of Energy Development and Use, 1888-2088. In Earth '88: Changing Geographic Perspectives, pp. 96-114. Washington: National Geographic Society.

. 1991. Institutional Issues in Capacity Building for Energy Technology Assessment. In Energy Systems, Environment, and Development, pp. 13-26. New York: United Nations Centre for Science and Technology for Development.

. 1992. The Case for Energy Efficiency Improvement as a Global Strategy. In Technologies for a Greenhouse-Constrained Society, ed. M. Kuliasha, A. Zucker, and K.J. Ballew, pp. 587-615. Boca Raton: Lewis.

. 1994. Sustainable Development in Geographic Perspective. Annals of the Association of American Geographers 84:541.

Williams, M. 1994. The Relations of Environmental History and Historical Geography. Journal of Historical Geography 20:3-21.

Wu, J., and Loucks, O. L. 1995. From Balance of Nature to Hierarchical Patch

Dynamics: A Paradigm Shift in Ecology. Quarterly Review of Biology 70(4): 439-66. 
Zimmerer, K.S. 1994. Human Geography and the "New Ecology": The Prospect and Promise of Integration. Annals of the Association of American Geographers 84(1): 106-125.

1996. Ecology as Cornerstone and Chimera in Human Geography. In Concepts in Human Geography, ed. C. Earle, K. Mathewson, and M.S. Kenzer, pp. 161-88. London: Rowman and Littlefield.

. 1999. The Overlapping Patchworks of Mountain Agricutlure: Toward a RegionalGlobal Landscape Model. Human Ecology 27(1): 135-65.

.2000. The Reworking of Conservation Geographies: Nonequilibrium Landscapes and Nature-Society Hybrids. Annals of the Association of American Geographers. 90(2): 356-369.

Zimmerer, K.S., and Young, K.R., eds. 1998. Nature's Geography: New Lessons for Conservation in Developing Countries. Madison: University of Wisconsin Press.

Zimmerman, J. 2001. The "Nature" of urbanism on the new urbanist frontier: sustainable development, or defense of the suburban dream? Urban Geography 22(3): 249-267. 